\title{
Local Development Policies: Challenges for Post-COVID-19 Recovering in Spain
}

\author{
Juan Carlos Rodríguez-Cohard*, Juan José Juste-Carrión ${ }^{* *}$, \\ Antonio Vázquez-Barquero****
}

\begin{abstract}
Territorial development policies facilitate productive diversification and job creation in rural and urban regions, where local actors manage and market local products. Thus, the connection of localities through urban and entrepreneurial networks helps the firms' interaction and the development of agrarian, industrial and service products for selling in national and international markets.

The creation of polycentric territories through new communication systems facilitate the towns and regions accessibility. Therefore, bottom-up policies and cooperation in times of post-COVID-19 recuperation reduces poverty and helps fight against inequality, permitting future territorial and social development.
\end{abstract}

Keywords: Endogenous Development; Local Development Policies; COVID-19

\section{The Impact of COVID-19}

The impact of the COVID-19 pandemic is a hard blow to regional and local economies throughout the world. In the Spanish case, the loss of employment is especially important because of the high percentage that tourism has on production as a whole and the most affected by COVID-19. The policies for recovery are mainly macroeconomic but we must bear in mind microeconomic actions as well in order to avoid the increase of personal and territorial inequalities as a result of unequal implementation.

Neoclassical approaches are conditioning the regional policies. Unfortunately for lagging regions, the process of circular and cumulative causation (Myrdal, 1957), the differences in human capital (Lucas, 1988) and the endogenous processes of innovation (Romer, 1986) make, on the one hand, an increase in returns for capital, reducing the approach for investment in poorer regions. On the other hand, it produces a change in the quality of migration: instead of pushing unqualified workers to migrate, the most qualified are the ones that find new opportunities in richer regions. Consequently, capital regions and the traditional richest areas in Europe have concentrated more and more economic power (Krugman, 1991), despite the effort of cohesion policies to balance the process of concentration.

\footnotetext{
*Associate Professor of Economics, University of Jaén (jccohard@ujaen.es)

** Associate Professor of Economics, University of Valladolid (juste@eco.uva.es)

*** Emeritus Professor of Economics, Universidad Autónoma de Madrid (vazquez-barquero@uam.es)

Edited by: Niccolò Cusano University

ISSN: $1593-0319$

Rodríguez-Cohard, J. C., Juste-Carrión, J. J., \& Vázquez-Barquero, A. (2020). Local Development Policies: Challenges for Post-COVID-19 Recovering in Spain. Symphonya. Emerging Issues in Management (symphonya.unicusano.it), (2), 41-54.
} 
For the coming years, the post-COVID-19 recovery process gives us the opportunity to implement a place-based policy, more balance to contribute to reduce inequalities between and within countries. The connections between high technology and industry should be key in order to address not only economic recovery, but to confront, if necessary, a future health crisis, and requires a special investment effort, especially in lagging regions, where a new generation of local development policies should be implemented.

The aim of this paper is to discuss whether it is convenient and viable to implement a new generation of local development policies to improve the social and economic capacity of lagging regions to catch up to the richer ones. Discussing macro and microeconomic policies for development, we formulate the following questions: Are macroeconomic policies paving the way for lagging regions to improve their competitiveness? How should local development policies evolve in order to allow lagging regions to be more resilient?

\section{The Background of Local Development Policies}

The crisis of the 1970s disrupted the economic foundations of Western developed countries. In Spain, lagging regions had to deal with a greater international economic liberalization, first with the entrance in the European Union, second with the challenge of the European Common Market, and third with the common currency. However, lagging regions in Spain had a sufficient wage gap with central regions in Europe to offset the differences in productivity.

The experience of locally based industrialization in Spain, generally in line with the concept of local production system (LPS), is strongly concentrated in the Mediterranean Arc regions. In the rest of Spain, especially in large areas of the interior, as is the case of Castilla and Leon, these experiences were few. In this regard, the Case of the Basque Country should be noted, where the industrialdeak program, as a strategy for productive restructuring in the face of the 80 s' crisis, was relevant. The combination of promoting infrastructure and equipment, the stimulus of endogenous resources, social economy and a favorable fiscal policy, has contributed toward encouraging innovation and the creation of sustainable employment.

From a sectoral perspective, the range of activities that mark the identity of LPSs were ample, especially in the field of light industry. A significant number of LPSs specialize in agro-industrial activities, such as the wood industry (linked to the exploitation of forest resources) and, above all, the agro-food industry. At the same time, tourism and service activities for SMEs start to diversify.

Local industrialization appears as a motor force for growth and structural change, a force for improvement in the living standards of the local population. Hence, policy makers uncover the need to implement the appropriate measures to strengthen the dynamism of this phenomenon and to recreate it, as far as possible, in other places with enough endogenous potential. In this sense, strategic planning becomes particularly important. Two areas of action in the field of local development policies should be mentioned: Active local employment policies and the Community Initiative LEADER. 
The promotion, since the mid-1980s, of the European matrix model of active policies for employment, within the framework of the so-called Local Employment Initiatives (LEIs), was a relevant factor in the implementation of local development policies. Focused on the active search for work, widely linked to the importance of SMEs, through employability, the promotion of self-employment and professional orientation actions, local employment initiatives were devoted to a better interrelationship between labor demand and supply. In this sense, Local Development Agencies, in those municipalities that could maintain an institution of this type, acquired growing importance as the backbone of the strategic planning process. The figure of the Local Development Agent appeared as a key factor of territorial animation, due to its work in the inventory and mobilization of local resources (Noguera et al., 2009).

The Community Initiative LEADER, in the case of rural areas, is a historical milestone. Since its launch in 1991, it was a basic pillar of rural development policy, which has become an increasingly important component of the Common Agricultural Policy.

\section{Globalization, Crisis and Decomposition of Local Development Policies}

The entrance in international markets of new industrial actors, such as China and other Southeastern Asian countries, eliminated the competitive advantages that lagging Spanish regions had in industrial mature activities. Before finishing the process of losing an international competitive advantage, the pushing effect of low interest rates because of the European monetary policy, led the Spanish economy to invest most of its resources into the construction sector in a speculative model of growth.

Traditional activities, such as wood, stone and ceramic tiles soared with the building sector. Local development policies were focused on a new market orientation, such as advanced services for small companies to pay. Examples of this change can be found in technology centers in Valencia and Andalucía (Quesada \& Rodríguez-Cohard, 2014), shifting the main purpose of the origin of local development policies in Spain: support the local endowment of productive factors. As a result, big companies linked to local production systems and international networks became the target of Spanish market technology centers (Quesada \& Rodríguez-Cohard, 2019) or on the contrary, local innovation policies should be dismantled (Quesada \& Rodríguez-Cohard, 2015).

External companies embedded in local production systems have opened up new opportunities to work in an interactive way with the more innovative local firms, but the knowhow for the use of advanced knowledge by Spanish small firms is weak and prevents them from taking part in innovation projects on a larger scale (Salazar-Elena \& Sánchez-Martínez, 2020).

The latter process is especially important in lagging regions of Southern countries, such as Spain, where for the small and medium firms there are no alternatives for using technology and innovation resources besides those provided by public funds coming from Cohesion Policy (Bachtrögler et al., 2020).

The economic-financial crisis of recent years has affected local development policy in the European context very negatively. The problems associated with the origin of 
the crisis and progression (bank failures, credit drought, under-consumption, company closures, massive unemployment, deterioration of public accounts, currency crisis, risk premium explosions, country bailouts...) have required solutions of a macroeconomic nature, to the detriment of microeconomic actions more sensitive to territorial specificities.

In view of this situation, which was aggravated in the Spanish case by the realestate crisis, the need for macroeconomic adjustment has overshadowed the issue of local development on the general discourse of the Community's economic guidelines (Ingellis et al., 2014). As a result, the long-term problems of towns and rural spaces have not been addressed during the crisis, leaving aside the important challenges the ousted workers of the building sector have in relation to learning new skills, especially important for both juniors and senior workers.

Policies of austerity have led southern European countries downward. In the case of Spain, apparent labor productivity is growing at a pace below the European Union and capital deepening has decreased (European Commission, 2020), which has widened the social gap of territorial inequalities between countries and regions. The most important problem derived from inequality is its capacity to continue through generations, linked to the inequality of opportunities. Preventing this vicious circle should be one of the main goals for the European Union.

In Europe, national institutional frameworks vary greatly, making for persistent long term inequalities throughout Europe (Acemoglu \& Robinson, 2012). This institutional disparity has contributed to reduce the offsetting effects of national policies while increasing inequalities, especially in Southern Europe, whose countries have experienced how austerity policies prevented compensate the social impacts of the financial crisis (Darvas \& Tschekassin, 2015). Furthermore, tendencies worsened because in the Central European countries, in addition to a broader welfare state and the effects of automatic stabilizers, there was less private indebtedness, all of which contributed to increased inequality between countries, and prevented local development policies to be adapted to new needs.

\section{A Disruptive Scenario: The Coronavirus Pandemic and Its Effects in Spain}

The appearance and rapid planetary spread of COVID-19 has led Spain, as many other countries, face challenges of unprecedented magnitude, both from a public health and from an economic point of view.

In any case, from the health perspective, as shown in Figure 1, it should be kept in mind that Spain is one of the ten most affected countries in the world, with more than

550,000 people infected since the beginning of the pandemic until mid-September 2020 , and with one of the highest mortality rates ${ }^{1}$.

From the economic perspective, the situation is also highly worrisome, according to the figures published and the projections handled by the various national bodies and official supranational institutions. Such estimates are subject to an unusually high degree of uncertainty, resulting from the volatility of the health scenario in the absence of the much desired vaccine. 
Figure 1: Top 20 Countries. Number of Infected People and Mortality Rate (100.000 inh.)

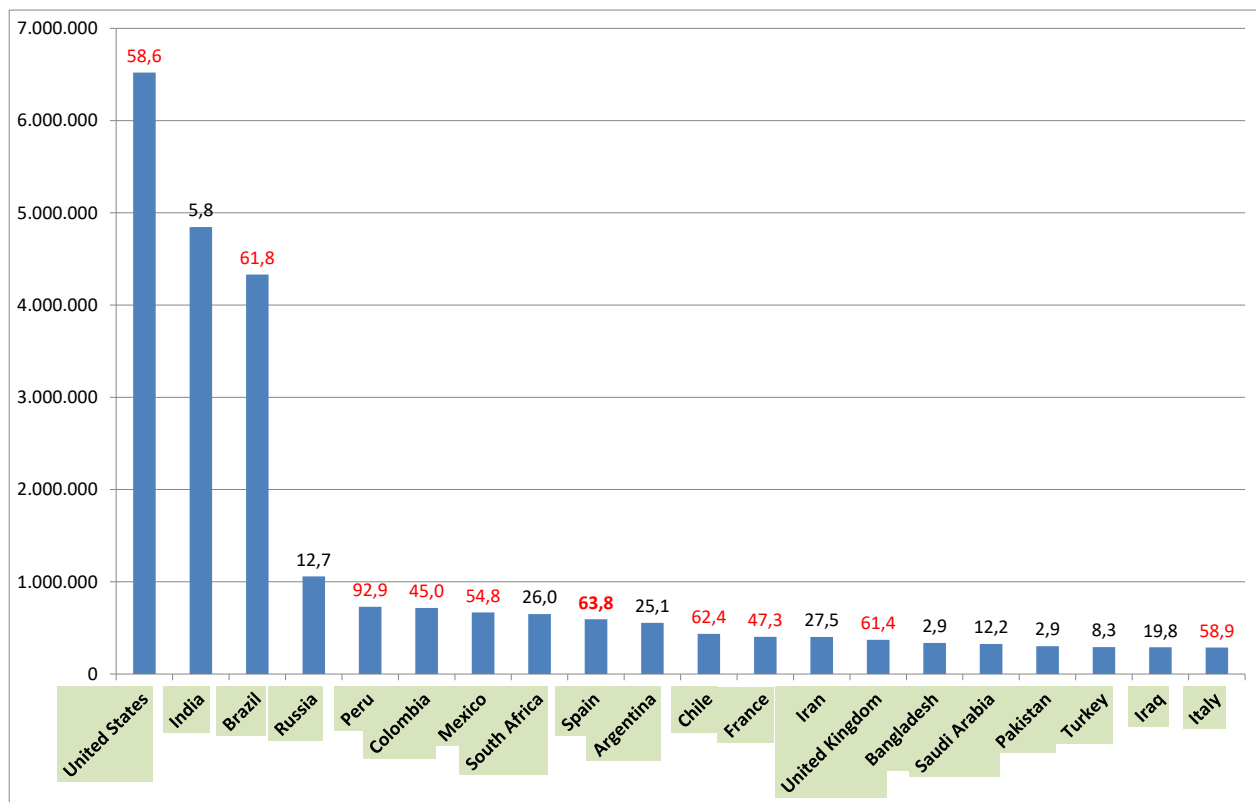

Source: Own elaboration from the data provided by Ministerio de Sanidad, Johns Hopkins University and United Nations.

In this sense, analyzing the figures relating to the evolution of GDP, as shown in Table 1, the enormous disruption that the coronavirus has caused during the first two quarters of 2020 for some countries of the EU can be observed. Thus, on a quarterly basis, Spain is among the five countries hardest hit during the first quarter, with the greatest economic contraction in France and Italy, where the pandemic began somewhat earlier.

Table 1: Growth Rates of GDP in Volume, 2019-2020

\begin{tabular}{|l|rrrr|rrrr|}
\hline GDP Growth & \multicolumn{3}{|c|}{$\begin{array}{c}\text { Percentage change compared with the } \\
\text { previous quarter }\end{array}$} & \multicolumn{4}{c|}{$\begin{array}{c}\text { Percentage change compared with the } \\
\text { same quarter of the previous year }\end{array}$} \\
\hline Countries & $\mathbf{2 0 1 9 Q 3}$ & $\mathbf{2 0 1 9 Q 4}$ & $\mathbf{2 0 2 0 Q 1}$ & $\mathbf{2 0 2 0 Q 2}$ & $\mathbf{2 0 1 9 Q 3}$ & $\mathbf{2 0 1 9 0 4}$ & $\mathbf{2 0 2 0 Q 1}$ & $\mathbf{2 0 2 0 Q 2}$ \\
\hline \hline Euro area & 0,3 & 0,1 & $-3,7$ & $-11,8$ & 1,4 & 1,0 & $-3,2$ & $-14,7$ \\
EU & 0,4 & 0,1 & $-3,3$ & $-11,4$ & 1,6 & 1,2 & $-2,7$ & $-13,9$ \\
Belgium & 0,4 & 0,5 & $-3,5$ & $-12,1$ & 1,6 & 1,3 & $-2,4$ & $-14,4$ \\
Germany & 0,3 & 0,0 & $-2,0$ & $-9,7$ & 0,8 & 0,4 & $-2,2$ & $-11,3$ \\
Ireland & 3,3 & 1,3 & $-2,1$ & $-6,1$ & 6,8 & 7,7 & 4,4 & $-3,7$ \\
Spain & 0,4 & 0,4 & $-5,2$ & $-18,5$ & 1,9 & 1,8 & $-4,1$ & $-22,1$ \\
France & 0,2 & $-0,2$ & $-5,9$ & $-13,8$ & 1,6 & 0,8 & $-5,7$ & $-18,9$ \\
Italy & 0,0 & $-0,2$ & $-5,5$ & $-12,8$ & 0,5 & 0,1 & $-5,6$ & $-17,7$ \\
Netherlands & 0,3 & 0,5 & $-1,5$ & $-8,5$ & 1,6 & 1,6 & $-0,3$ & $-9,0$ \\
Austria & $-0,2$ & $-0,2$ & $-2,4$ & $-10,4$ & 1,4 & 0,4 & $-2,8$ & $-12,9$ \\
Poland & 1,2 & 0,2 & $-0,4$ & $-8,9$ & 4,1 & 3,5 & 1,7 & $-7,9$ \\
Sweden & 0,3 & 0,1 & 0,2 & $-8,3$ & 1,7 & 0,7 & 0,7 & $-7,7$ \\
\hline
\end{tabular}

Source: Eurostat. Newrelease Euroindicators no 133/2020; 8 September 2020. 
However, the data for the second quarter are truly devastating. From the $5.2 \%$ fall experienced in March, the country technically entered a recession in June with a decrease of $18.5 \%$, an unprecedented figure in times of peace, only surpassed by the United Kingdom.

If the variation in GDP is considered in interannual terms, the situation is very similar, except that on this occasion, during the second quarter, the Spanish economy recorded the greatest shrinkage (-22.1\%), ahead of the United Kingdom, France and Italy, doubling Germany and well above the EU average and that of a large part of the EU countries.

The most immediate consequences of this situation are reflected in the behavior of the labor market with the destruction of a huge number of jobs. This dramatic picture shows the contraction of $7.6 \%$ experienced during the second quarter, two points above the next most affected country in these terms, Hungary, much more pronounced than in the whole of the EU and the Eurozone, and in clear contrast to the figures recorded by the rest of the large countries of the Union, especially Germany and Poland.

The particular Spanish productive structure, with a high burden of closely linked sectors, such as tourism and hospitality industry, which, together with the retail trade, were strongly affected during the lockdown and are highly vulnerable to the adverse evolution of events. They help explain, in addition to the fall in exports, a good part of that sharp destruction of employment, estimated at 1,074,000 people during the second quarter ${ }^{2}$.

Estimates predict a level of unemployment at the end of the year above $20 \%$, and the closure of more than 240,000 companies (Funcas, 2020). Table 2 reflects the largest expected fall in GDP, by the end of this year, within the group of advanced economies: $12.8 \%$, like Italy, followed closely by France $(-12.5 \%)$. If the recovery forecast for 2021 occurs - favored by the recomposition of international trade and tourism -, of $6.3 \%$ of the GDP, a figure subject to enormous uncertainty, it will only allow for the recovery of part of the destroyed productive fabric.

This is undoubtedly a challenge for public finances, which were badly damaged during the previous crisis, in order to try to soften the consequences of the pandemic by assisting people (unemployment benefits and job retention programs -ERTEs-, or aid to individuals and families at risk of poverty) and businesses (subsidies or tax moratoria, ...). With expanding expenditure and lower tax incomes due to the decline in economic activity, the public deficit will rise in Spain from $2.8 \%$ of GDP to almost $14 \%$ in 2020. It will reach $23.8 \%$ in the United States and $16 \%$ in Brazil, two of the countries hardest hit by the spread of the disease. This variable, in line with growth forecasts, will be above $8 \%$ in 2021 , three points higher than the figure for the Eurozone and very far from Germany, which could once again lead to a rise in the risk premium on international financial markets (Table 2).

In fact, public debt will reach levels unknown since the late 19th and early 20th centuries: above $120 \%$ of GDP and tending to remain and even increase in 2021. A situation very similar to that of France and especially striking in the United States and Italy, which already had a public debt of over 100\% of GDP in 2019, and especially in Japan, whose figure will be around $270 \%$ by the end of the year. The contrast with advanced economies with healthier public expenditures, and therefore with more room to maneuver, like Germany and even the United Kingdom, is clear. 
The predictions of a possible K-shaped recovery, slower and potentially associated with a worsening of the current health and economic context, are worrisome for Spain, insofar as they would imply an increase in income inequalities between people, sectors and regions and this would also hamper the already slow convergence with the more prosperous countries.

Table 2: Economic Projections in Some of the Most Important Economies in the World

\begin{tabular}{|c|c|c|c|c|c|c|c|c|c|c|c|c|}
\hline \multirow[b]{2}{*}{ Countries } & \multicolumn{4}{|c|}{ GDP } & \multicolumn{4}{|c|}{ Fiscal Balance } & \multicolumn{4}{|c|}{ Gross Public Debt } \\
\hline & 2018 & 2019 & 2020 & 2021 & 2018 & 2019 & 2020 & 2021 & 2018 & 2019 & 2020 & 2021 \\
\hline World & 3,6 & 2,9 & $-4,9$ & 5,4 & $-3,1$ & $-3,9$ & $-13,9$ & $-8,2$ & 81,2 & 82,8 & 101,5 & 103,2 \\
\hline Advanced Economies & 2,2 & 1,7 & $-8,0$ & 4,8 & $-2,7$ & $-3,3$ & $-16,6$ & $-8,3$ & 104,0 & 105,2 & 131,2 & 132,3 \\
\hline United States & 2,9 & 2,3 & $-8,0$ & 4,5 & $-5,8$ & $-6,3$ & $-23,8$ & $-12,4$ & 106,9 & 108,7 & 141,4 & 146,1 \\
\hline Euro area & 1,9 & 1,3 & $-10,2$ & 6,0 & $-0,5$ & $-0,6$ & $-11,7$ & $-5,3$ & 85,8 & 84,1 & 105,1 & 103,0 \\
\hline Germany & 1,5 & 0,6 & $-7,8$ & 5,4 & 1,9 & 1,5 & $-10,7$ & $-3,1$ & 61,9 & 59,8 & 77,2 & 75,0 \\
\hline France & 1,8 & 1,5 & $-12,5$ & 7,3 & $-2,3$ & $-3,0$ & $-13,6$ & $-7,1$ & 98,1 & 98,1 & 125,7 & 123,8 \\
\hline Italy & 0,8 & 0,3 & $-12,8$ & 6,3 & $-2,2$ & $-1,6$ & $-12,7$ & $-7,0$ & 134,8 & 134,8 & 166,1 & 161,9 \\
\hline Spain & 2,4 & 2,0 & $-12,8$ & 6,3 & $-2,5$ & $-2,8$ & $-13,9$ & $-8,3$ & 97,6 & 95,5 & 123,8 & 124,1 \\
\hline Japan & 0,3 & 7,0 & $-5,8$ & 2,4 & $-2,5$ & $-3,3$ & $-14,7$ & $-6,1$ & 236,6 & 238,0 & 268,0 & 265,4 \\
\hline United Kingdom & 1,3 & 1,4 & $-10,2$ & 6,3 & $-2,2$ & $-2,1$ & $-12,7$ & $-6,7$ & 85,7 & 85,4 & 101,6 & 100,5 \\
\hline Canada & 2,0 & 1,7 & $-8,4$ & 4,9 & $-0,4$ & $-0,3$ & $-12,6$ & $-5,8$ & 89,7 & 88,6 & 109,3 & 108,8 \\
\hline Emerging economies & 4,5 & 3,7 & $-3,0$ & 5,9 & $-3,8$ & $-4,9$ & $-10,6$ & $-8,5$ & 48,9 & 52,4 & 63,1 & 66,7 \\
\hline
\end{tabular}

Source: International Monetary Fund (IMF): World Economic Outlook, Update Document, June 2020.

In order to face this unusual situation, from the perspective of economic policy, some actions have been forged in recent months to try to contain the situation in the short term. The evolution of events, to which we can add the whole battery of resources that, with a longer-term projection, will be implemented in the coming years, will follow the agreements reached last July at Community level on the budget for the period 2021-2027 and the European Recovery Plan.

With regard to the first group of measures, there is a wide range of actions that have been reflected in the implementation of the general State budget, both from the perspective of public expenditure and tax income ${ }^{3}$. Broadly speaking, the following aspects should be highlighted:

- On the expenditure side, the reinforcement of the Contingency Fund, aimed at improving the coverage of health care; the financial support for the regions, for an amount of 2,500 million $€$, in order to support the additional health expenditure of the Autonomous Communities, and various facilities and aid in favor of groups such as self-employed workers, dependent persons, children affected by the interruption of their school learning or people in a situation of poverty and social exclusion.

- On the income side, the postponement for SMEs and self-employed workers of the payment of taxes and contributions; application and extension of exemptions to social security payment companies aimed at maintaining the employment directly affected by the COVID-19, by means of ERTEs; reductions in social security contributions for workers with permanent discontinuous contracts and agricultural workers during periods of inactivity.

- Accompanying measures of a sectoral nature aimed at favoring certain activities (tourism, automotive, energy, insurance...) and companies, especially SMEs, with a boost to the role of the Official Credit Institute (ICO). 
The margin for implementing these harsh measures is limited compared to countries with greater fiscal capacity, such as Germany, given the delicate state of public accounts and their future sustainability, which is rated by the financial markets.

This situation, together with the structural insufficiency of tax collection, makes the second group of measures essential. Arising from the Community context, and whose most singular element is the European Recovery Plan, the so-called Next Generation EU is a mechanism for strengthening the EU's Multi-annual Financial Framework for the period 2021-2027, endowed with 1.0743 billion euros, aimed at revitalizing the economies of the Member States (European Council, 2020).

With a global amount of 750,000 million Euros, through massive debt issuance, it has as its fundamental program the Recovery and Resilience Mechanism, which absorbs 672,500 million $(360,000$ in the form of grants and 312,000 in the form of loans). In order to attract these resources, countries must present their national recovery plans, detailing the reform and investment program for the period 20212027. The granting of the funds will be subject to the positive evaluation of these plans and the satisfactory fulfillment of the goals and objectives.

Spain has obtained an allocation of 140,000 million euros $(72,700$ in the form of direct aid and the rest on credit), being the second most benefited country after Italy, given the greater economic and health impact of the COVID-19. This funding represents an important boost. However, it has been criticized because its budgetary limitation (only 5.4 per cent of the GDP of the EU-27) for such an extraordinary and unpredictable situation; its long implementation schedule, more than five years, in view of the urgency of demand needs in a scenario of weak consumption (and precautionary savings); its preferential orientation towards structural reforms largely linked to the ecological and digital transition, rather than to the immediate reactivation of the economy; and its conditionality, embodied in the application of adjustments and reforms whose difficult implementation may represent a serious obstacle to the release of payments (Bandrés et al, 2020).

The gravity of the Spanish situation and the possible financial weakness makes it advisable to resort to additional sources, in line with the possibilities offered by the EU:

- The credits granted by the European Investment Bank (EIB), especially indicated to finance private investments.

- The maximum use of funds contemplated in the SURE program focused on protecting citizens and mitigating the severity of the socio-economic impact of the pandemic.

- The use of the European Stability Mechanism (MEDE), aimed at guaranteeing financial stability in the euro area by assisting countries in the euro area that are suffering or at risk of suffering economic difficulties. An instrument that is not very popular, as it is associated in the collective memory with the harsh rescue of some countries in the previous financial crisis, which resulted in extensive cuts in public spending and devaluation of wages and pensions.

- In the area of monetary policy, in the face of the asymmetries inherent in the fiscal policy of the States, the purchase of assets by the European Central Bank, within the framework of Quantitative Easing, a vital injection of cheap money, in the current favorable context of low interest rates. 
A panorama definitively unsettling from the perspective of local development. Local development policy, insofar as it is determined by pressing macroeconomic needs, could once again be overshadowed.

However, the articulation of answers to the crisis provides an opportunity to appreciate the usefulness and viability of "development from below" in times of difficulty, as will be attempted in the following pages. Thus, a post-COVID-19 horizon is opening up in which to locate local development initiatives, potentially compatible with future challenges in terms of sustainability and digitalization, based on the design of projects that, far from being assimilated to a re-edition of "Plan E", have sufficient power to carry over time, in a climate of public-private and interterritorial cooperation. This is essential in order to make the most of the endowments of funds for local/rural development and territorial cohesion in the European Recovery Plan and, above all, in the Multiannual Financial Framework, while making the best use of the savings of those municipalities with a surplus in their municipal budget.

\section{The Need to Encourage Micro-territorial Policy for the Post-COVID-19 Recovery}

The process of economic recovery will be difficult, putting at risk better salaries for employees, the adoption of best technologies for companies and the implementation of training and education actions. However, the wealth of the society as a whole depend on territories endogenous potential, which is embedded in the metropolitan, urban and rural territories. In this sense, it is especially important to bear in mind that rural spaces present very different territorial situations, where a rural life style is anchored in preurbanised structures of medium size cities and town networks.

For preventing rural depopulation, it is essential to push the agroindustry forward in order to make it more competitive within international markets. European farmers are competing in an increasingly challenging environment. It is necessary to maintain their standard of living, not only with subsidies but also with the opportunity to improve their role in global value chains. Local development policies in combination with a new Common Agriculture Policy more focused towards competitive challenges is needed. Upgrading and diversifying industrial and service activities in lagging territories is possible by changing the current no industrial policy to a general agreement for investments in rural and deprived regions in Europe and increasing their capacity to better compete in a globalized world. In this sense, technological centers linked to agrarian institutes working together with regional universities and local firms and farmers are useful territorial networks for improving and adapting food and other agricultural products for international markets.

The consequence of not addressing this problem from a micro and macroeconomic approach is causing a polarization of society, putting at risk social cohesion, security, and territorial disparities, since metropolitan regions reach, on average, higher living standards than other regions (Veneri \& Murtin, 2016; Odendahl et al, 2019). Public and private investments in infrastructure, technology, education and technical skills should be addressed instead of allocating resources to elites living in big and well 
connected cities (Stiglitz, 2019), such as part of the funds of Common Agriculture Policy does, instead of focusing these to the professional farmers.

Once austerity policies have shown to be ineffective in many respects, the space for micro-territorial actions as an alternative is opening up. Now is the time for smart investments in a green and more diffuse European economy. Small infrastructure networks connecting systems of rural areas, household services, and health systems in rural territories, elderly care, renewable energies, and other activities could be put in motion in order to avoid losing human capital with capacity to trigger development processes in the coming years, instead of contemplating the brain focused towards big cities.

In the case of rural development policies, the current phase of LEADER-CLLD (2014-2020), with greater financial flexibility, was oriented towards reinforcing local governance and cooperation. However, much remains to be done in this area (Esparcia \& Abbasi, 2020), which is not related to cutting funds in recent years. The budgetary period that is on the horizon (2021-2027), should be aimed at deepening this governance, through inclusive mechanisms. The effort to strengthen the LEADER initiative, with greater influence in the Rural Development Programmes (RDPs) of the regions, is possible, although the reduction of financial resources resulting from Brexit is emerging as a formidable obstacle to its achievement.

The need for knowledge in rural spaces is paramount for improving the income of the population in lagging regions. Centers for linking innovation activities to agroindustry must go beyond tourism and services of low added value. Agricultural policies should be more connected to the objective of linking activities in international value chains, in combination with local development policies, which could focus their attention in improving the capacity of small and medium local firms to participate in international networks, using the interface some external companies have been putting in motion during the last years. Furthermore, territorial identity could be used as a catalyst to promote symbolic functions in some spaces in order to improve the local capacity to act (Capello, 2018; Harfst et al. 2020).

The abandonment of labor active policies, paradoxically in the toughest period of the crisis in some regions of Spain, has shown how intense the top-down focus of austerity policies has been and why we need to change the local development policies for the future. Most of the problems to address are in relation to the interpretation of public funds as an opportunity for capturing them. Either in politics, in the case of public bodies, or in the case of people using them as social subsidies, as training courses, for instance, instead of using them for socioeconomic investments in the territorial human and physical capital.

In our view, some of the main problems of local development policies to be implemented are in relation to top-down priorities and sectorial perspectives. This is the case of processes of territorial strategic planning with a low capacity to propose local initiatives. In some cases, they were asked for solutions in order to deal with the financial crisis, but despite having a list of projects from different governments waiting to be delivered, their capacity to adopt a territorial decision has been null. In the same vein, the latter have hampered the opportunities for cluster policies to offer territorial solutions. The so-called Agrupación Empresarial Innovadora (AEI) has been one of the main instruments for cluster policy in Spain, issued with an intense place-based focus, but it was turned into a sectorial one, with a much lesser impact on territorial capacity to push local development projects forward. New forms of co- 
governance should be explored, in order to combine the best of top-down and bottomup approaches (Morgan \& Sabel, 2019).

The coordination of economic, political and social actors of different tiers of government plays a central role in the implementation of local economic policy. However, the lack of coordination and/or the imposition by more powerful interest groups may stop the development process. Therefore, the governance of territorial development faces the challenge of needing a pertinent institutional framework and agreement on the objectives, actions and priorities of the economic, political and social actors (Vázquez-Barquero \& Rodríguez-Cohard, 2016).

\section{Final Comments}

In the current scenario of searching for how to apply the best option for recovery, it is convenient to pay greater attention to manufacturing as a lever for territorial change. Its strong dragging effect, given its links along the value chain, makes it a powerful engine for productive diversification and job creation, and therefore for the growth of local wealth. Hence, the interest in increasing its relative weight in GDP, in accordance with the Community guidelines, through industrial policy intervention, sponsored by public authorities at all levels, within an atmosphere of intelligent Keynesianism, investing in the forces of development (Vázquez-Barquero, 2010) and preventing the corruption.

The COVID-19 pandemic has corroborated the vulnerability of the Spanish model, intensively based on low added services and the building sector. The temptation to prioritize macroeconomic adjustment over people's needs to be abandoned. This is not the time. Now Europe needs a significant volume of resources for economic revitalization and employment generation, with industry as the preferred destination from a long-term perspective. This would lead to greater investment in $R \& D$, with the aim of promoting continuous improvement of products, processes management, models and marketing strategies, and continuous progress in human capital formation, resulting in productivity improvements and eventual wage increases (and, therefore, higher income for the public coffers via social contributions and taxation).

It is necessary to encourage the third-rank system of cities, where most rural areas are connected in order to take advantage of a more polycentric territory (Vázquez Barquero, 2012) making the most of strategic spatial interactions (Védrine, 2020). The periods of cohesion policy have been intensively dedicated to infrastructure (Crescenzi \& Giua, 2020) but oriented to better communicate big cities and to make more accessible the second-rank system of cities. The results have proved a wider territorial inequality in terms of accessibility to towns and rural spaces in some regions of Spain, where depopulation processes have been intensified.

The capacity to mobilize the endogenous potential inherent in manufacturing activity is often linked to the presence of natural and material resources in a given area. In this respect, the agro-food industry is particularly important as a vehicle for diversifying production in predominantly agricultural areas (Sanz Cañada, 1993). The presence of PDOs, PGIs, Guarantee Marks... has a positive impact throughout the entire value chain, from agriculture (with the revaluation of land and agricultural products), to the final consumer (whose diet is improved), going through industry and distribution (with more prestigious products). To the extent that these 
circumstances translates into the maintenance of agricultural activity and jobs, they contribute to the necessary fixation of the population in the territory (Caldentey, 1998).

In this context, the interest in promoting initiatives of concentric diversification using the territorial capital of Social Economy should be taken into account (Juste Carrión et al., 2011). The link between population and territory, self-employment, the role of SMEs, the mobilization of endogenous potential, and the importance of human capital and democratization in decision-making is a lever for development in rural spaces. Social innovation initiatives through cooperatives should be appropriate channels to spread new ways of gaining competitive advantage in rural areas, and providing new elements of welfare.

The rural environment should not necessarily mean economic backwardness or poverty. In this sense, local development policy in rural areas has a Herculean task ahead of it, in a globalized and increasingly complex world, with the shadow of trade wars and climate change always lurking. A combination of unemployment and depopulation is very dangerous for territorial and social cohesion. A new local development policy in lagging regions more oriented to people left behind because of globalization, instead of only in capital endowment is an issue of dignity, not only an instrument to meet economic goals (Banerjee \& Duflo, 2019).

In sum, place-based policies need to bear in mind features conditioning the success of local development policies implementation, such as the quality and the capacity for cooperation of governments, the absorptive capacity of regions and the presence of cultural and social particularities (Berkowitz et al., 2020). Developing companies' networks, regional innovation systems, sectorial institutions and improving the level of social and economic structures are important. All these elements push territorial development processes in Europe forward and are fundamental pillars for fighting against inequalities (Vázquez-Barquero \& Rodríguez-Cohard, 2019). Furthermore, they also contribute towards extending opportunities for choosing occupations and improving skills, preventing increasing territorial and social inequalities in the future.

\section{Bibliography}

Acemoglu, D., \& Robinson, J. A. (2012). Why Nations Fail. The Origins of Power, Prosperity and Poverty. New York: Crown Publishers.

Bachtrögler, J., Fratesi, U. \& Perucca, G. (2020). The Influence of the Local Context on the Implementation and Impact of EU Cohesion Policy. Regional Studies, 54(1), 21-34.

http://dx.doi.org/10.1080/00343404.2018.1551615

Barnerjee, A. V. \& Duflo, E. (2019). Good Economics for Hard Times: Better Answers to Our Biggest Problems. London: Allen Lane.

Bandrés, E., Gadea, L. Salas, V. \& Sauras Y. (2020): España y el Plan Europeo de Recuperación. Cuadernos de Información Económica, 277, 9-23, july-august, Funcas.

Berkowitz, P., Monfort, P. \& Pienkowski, J. (2020). Unpacking the Growth Impacts of European Union Cohesion Policy: Transmission Channels from Cohesion Policy into Economic Growth. Regional Studies, 54(1), 60-71.

http://dx.doi.org/10.1080/00343404.2019.1570491

Caldentey, P. (1998). Nueva Economía Agroalimentaria. Madrid: Editorial Agrícola Española S.A.

Capello, R. (2018). Interpreting and Understanding Territorial Identity. Regional Science, Policy \& Practice, 11, 141-158. 
Crescenzi, R. \& Giua, M. (2020). One or many Cohesion Policies of the European Union? On the Differential Economic Impacts of Cohesion Policy across Member States. Regional Studies, 54(1): 10-20.

http://dx.doi.org/10.1080/00343404.2019.1665174

Darvas, Z. \& Tschekassin, O. (2015). Poor and Under Pressure: The Social Impact of Europe's Fiscal Consolidation, Bruegel Policy Contribution, 4, March. Retrieved from

https://bruegel.org/2015/03/poor-and-under-pressure-the-social-impact-of-europes-fiscal-consolidation

Esparcia, J. \& Mesa, A, R. (2018). LEADER en España: Cambios Recientes, Situación Actual y Orientaciones para su Mejora. Resumen, Conclusiones y Propuestas del Equipo UDERVAL (Unidad de Desarrollo Rural y Evaluación de Políticas Públicas). Instituto Universitario de Desarrollo Local, Universidad de Valencia.

European Commission (2020a). Country Report Spain, Commission Staff Working Document, Brussels.

European Commission (2020b): Policy Measures Taken Against the Spread and Impact of the Coronavirus.

https://ec.europa.eu/info/live-work-travel-eu/health/coronavirus-response/jobs-and-economyduring-coronavirus-pandemic en

European Council, (2020). European Council Conclusions on the Recovery Plan and Multiannual Financial Framework for 2021-2027. 17-21 July 2020, EUCO 10/20, Brussels.

FUNCAS (2020). Previsiones para la Economía Española 2020-2021, FUNCAS, Madrid.

Harfst, J., Wirth, P. \& Marot, N. (2020). Utilizing Endogenous Potentials through EU Cohesion Policy: Examples from Central Europe. European Planning Studies.

http://dx.doi.org/10.1080/09654313.2020.1712675

Ingellis, G., Calvo, R., Greco, L. \& Chiarello, F. (2014). Políticas de Desarrollo Local en España y Italia: del Análisis A Una Propuesta para el Futuro. V Jornadas de Desarrollo Local de la Comunidad Valenciana, Valencia, 11 de diciembre de 2014.

Juste Carrión, J.J., Gómez García, J. M. \& Fernández Arrufe, J. E. (2011). Economía Social y Desarrollo Local/Rural. Un Análisis de sus Sinergias, Estudios de Economía Aplicada, 29(1), 189222.

Krugman, P. (1991). Increasing Returns and Economic Geography. Journal of Political Economy, 99(3), 483-499.

Lucas, R. E. (1988). On the Mechanics of Economic Development. Journal of Monetary Economics, 22(1), 3-42.

Morgan, K. \& Sabel, C. (2019). The Experimentalist Polity, in Simmons, T.: Radical Visions of Future Gorverments, London: NESTA: 75-81.

Myrdal, G. (1957). Economic Theory and Underdeveloped Regions, London: Gerald Duckworth.

Noguera Tur, J., Esparcia Pérez, J. \& Pitarch, M. D. (2009). Gestión y promoción del desarrollo local. Valencia: Publicaciones de la Universidad de Valencia.

Odendahl, C., Springford, J., Johnson, S. and Murray, J. (2019). The big European sort? The Diverging Fortunes of Europe's Regions. Center for European Reform, www.cerc.eu

Quesada Vázquez, J. \& Rodríguez-Cohard, J. C. (2014). Origin and Evolution of Innovation Policies in Andalusia. Arethuse: Scientific Journal of Economics and Business Management, 1(2), 71-94.

Quesada Vázquez, J. \& Rodríguez-Cohard, J. C. (2015). Implementation Challenges in Cluster Policy Making: the Case of the Andalusian Furniture Technology Centre. Prometheus, 33(2), pp. 113-137.

Quesada Vázquez, J. \& Rodríguez-Cohard, J. C. (2019). Subsidiary Upgrading and Regional Innovation Policies: The Case of Valeo Lighting Systems Spain and the Andalusian Plastic Innovation Center. Environment and Planning C: Politics and Space, 37(5), 908-928.

Romer, P. M. (1986). Increasing Returns and Long-Run Growth. Journal of Political Economy, 94(5), 1002-1037.

Salazar-Elena J.C. \& Sánchez-Martinez, M. (2020). Regional Innovation Observatory, Country Report Spain, 


\section{http://rio.jrc.ec.europa.eu}

Sanz Cañada, J. (1993). Industria Agroalimentaria y Desarrollo Regional. Ministerio de Agricultura, Pesca y Alimentación, Serie Estudios, vol. 78, Madrid.

Stiglitz, J. E. (2019). People, Progress and Profit: Progressive Capitalism for an Age of Discontent. New York: WW Norton.

Vázquez-Barquero, A. (2010). The New Forces of Development, Singapore: World Scientific.

Vázquez-Barquero, A. (2012). Innovative Regions: Strategic Spaces for Development, in P. Cooke, M. D. Parrilli, \& J. L. Curbelo (Eds.): Innovation, Global Change and Territorial Resilience. Cheltenham: Edward Elgar: 137-149.

Vázquez-Barquero, A. \& Rodríguez-Cohard, J. C. (2016). Endogenous Development and Institutions: Challenges for Local Development Initiatives. Environment and Policy C: Government and Policy, 34(6), 1135-1153.

Vázquez-Barquero, A. \& Rodríguez-Cohard, J. C. (2019). Local Development in a Global World: Challenges and Opportunities, Regional Science, Policy and Practice, 11, 885-897.

Védrine, L. (2020). Allocation of European Structural Funds, Decentralization and Strategic Spatial Interaction. Regional Studies, 54(1), 72-82.

Veneri, P. and Murtin, F. (2016). Where is Inclusive Growth Happening? Mapping Multidimensional Living Standards in OECD Regions, OECD Statistics Working Papers/01.

\footnotetext{
Notes

${ }^{1}$ The number of infected people in the world, as of September 14, 2020, exceeds 29,035,000, with just over 924,000 deaths. These figures are intended to be more illustrative than demonstrative, and should be interpreted with due caution, given the different ways in which contagion and deaths are officially recorded in different countries. In any case, they represent a minimum starting point in the perception of the real magnitude of the tragedy, especially in those countries more severely punished. In the case of Spain, estimates centered on the movements of the Civil Registry, Social Security data on pensions and statistics on funeral services, give a figure of approximately 50,000, a figure much higher than the nearly 30,000 officially recognized by the Ministry of Health.

${ }^{2}$ This figure does not include workers affected by job retention programs (ERTE) with suspension of employment, who are still considered employed, according to the Eurostat and ILO methodology applied in the Labor Force Survey (LFS). After having affected almost 3.4 million employees, as of June 30 there were still about 1,800,000 in this situation.

${ }^{3}$ For more information on the different and varied measures that have been adopted at the dawn of events, both in Spain and in the rest of the EU countries, see the document published by the European Commission in August 2020 available at:
}

https://ec.europa.eu/info/live-work-travel-eu/health/coronavirus-response/jobs-and-economy-duringcoronavirus-pandemic en. 